중석 광미를 사용한 시멘트 모르타르의 입도 및 수열합성온도별 물리적 특성

\author{
§추용식* · 서성관* · 최성범** · 김경만** · 홍석환** \\ *한국세라믹기술원 에너지환경본부, **영월산업진흥원 광물소재사업팀
}

\title{
Properties of Cement Mortar as Particle Size and Hydrothermal Synthesis Temperature Using Scheelite Tailing
}

\author{
${ }^{\S}$ Yong Sik Chu*, Seong Gwan Seo*, Sung Bum Choi**, \\ Gyoung man Kim** and Seok Hwan Hong** \\ *Energy \& Environmental Division, Korea Institute of Ceracic Eng. \& Tech., Jinju 52851, Korea \\ **Department of Mineral Materials Business, YEMI, Yeongwol 26240, Korea
}

\begin{abstract}
요 약
본 연구에서는 국내에 적절한 환경처리 없이 방치되어 있는 중석광미를 활용하여, 중석 광미 입도별 시멘트 모르타르 제조 후 수 열합성온도별 물리적 특성을 확인하였다. 시멘트 모르타르 혼합 시 물-시멘트비는 $75 \%$ 로, 모래-시멘트비는 $400 \%$ 로 고정하였으며, 광미는 모래(모래 중량 대비 $0 \sim 50 \%$ )를 치환하여 사용하였다. 저비소 및 고비소 광미의 입경은 $9.3 \sim 53.0 \mu \mathrm{m}$ 로 제어하였고 수 열합성온도는 승온 속도 $2{ }^{\circ} \mathrm{C}$ 로 고정하여 $60 \sim 180^{\circ} \mathrm{C}$ 에서 6 시간 동안 유지하였다. 수열합성 온도가 증가에 따라 압축강도는 상승 하였으며, 60 분 분쇄 저비소 및 고비소 광미를 $30 \%$ 혼합 시 압축강도는 각각 $55.2 \mathrm{MPa}$ 및 $54.5 \mathrm{MPa}$ 로, 비교시편 보다 $300 \%$ 이 상 항상되는 결과를 도출하였다.
\end{abstract}

주제어 : 저비소 광미, 고비소 광미, 수열합성, 입도제어, 폐기물 재활용

\begin{abstract}
Cement mortar was hydrothermal-synthesized with particle size of tailings using scheelite tailings deposited without proper treatment, and its physical properties were investigated. The mixing ratios of water-cement and sand-cement were fixed at $75 \%$ and $400 \%$, respectively, during preparing cemnt mortar, and the sand was replaced by the tailings at $0 \sim 50 \%$. The particle size of tailings was controlled at $9.3 \sim 53.0{ }^{\circ} \mathrm{C}$, and the hydrothermal temperature was kept at $60 \sim 180{ }^{\circ} \mathrm{C}$ for 6 hours after the temperature increased to pretermined temperature with $2{ }^{\circ} \mathrm{C}$ heating rate. The compressive strength increased with increasing hydrothermal temperature. The compressive strengths were 55.2 MPa and 54.5 MPa when the mortars were prepared with $30 \%$ low arsenic and high arsenic tailings after 60 min grinding. The compresiive strenght was enhanced $300 \%$ compared with reference sample.
\end{abstract}

Key words : low arsenic tailngs, high arsenic tailngs, Hydrothermal Synthesis, particle size control, waste recycling

\footnotetext{
Received : October 4, $2019 \cdot$ Revised : November 12, $2019 \cdot$ Accepted : December 5, 2019

$\S$ Corresponding Author : Yong Sik Chu (E-mail : yschu@kicet.re.kr)

Energy \& Environmental Division, Korea Institute of Ceramic Engineering \& Technology, 101, Soho-ro, Jinju-si, Gyeongsangnam-do 52851, Korea

(C) The Korean Institute of Resources Recycling. All rights reserved. This is an open-access article distributed under the terms of the Creative Commons Attribution Non-Commercial License (http://creativecommons.org/licenses/by-nc/3.0/), which permits unrestricted non-commercial use, distribution and reproduction in any medium, provided the original work is properly cited.
} 


\section{1. 서 론}

국내 금속광산은 유용광물자원의 국내 확보를 위해 활발히 개발되어 왔으나, 1980년대 이후 경쟁력을 상실 하여 대부분 휴광 또는 폐광된 상태이다. 이에 따라 국 내 광산 폐기물(폐석, 광미)은 법규정에 따라 광산 주변 에 그대로 적치되어 있다. 정부는 광산 폐기물을 재활 용하려는 지속적인 연구개발을 하였으며, 환경정화 차 원에서 매년 150 억원 수준의 예산을 지원하여 폐수정 화 및 폐석유실 방지 등의 공해방지 사업을 시행하고 있다 ${ }^{1)}$.

강원도 상동지역에서도 대한중석이 회중석을 개발하 면서 40년간 폐기하였던 광미가 약 1,200 만톤 정도 적 치되어 있다. 이에 따라 광미댐의 국부적인 토사유출과 댐의 팽창 등에 의해 댐 전체의 구조적인 안정성이 문 제되고 있다 ${ }^{1)}$. 이에 대한 단기대책으로는 국부적인 댐 보수 방법이 있지만, 보다 장기적 안정적 해결방법을 도 출하는 것이 바람직하다. 이를 위해 다양한 연구가 수 행되었으며, 이중 콘크리트 분야로의 적용을 위한 연구 도 수행된 바 있다. 최 등은 상동 중석광미를 사용하여 흙도로 포장용 재료로의 사용가능 여부에 대한 실험을 진행하였으며, 자기충전 콘크리트로의 적용 가능성을 검 토하기도 하였다. 자기충전 콘크리트에서는 상동광미 혼 합량 증가에 따라 압축강도는 감소하였으며, 탄산화 속 도도 빨라진다고 하였다2-3). 따라서 상동광미 혼합 조건 에서도 물리적 특성이 하락하지 않는 방안이 도출되어 야 한다. 또한 양생기간이 길지 않고 제조 후 $1 \sim 2$ 일 이내에 제품화 될 경우, 더욱 효과적인 사용방안이 될 수 있을 것이다. 일반적으로 양생기간을 짧게 유지하고, 조기에 물성을 발현하기 위해서는 상압증기 양생 또는 수열합성(Hydrothermal synthesis)에 의한 고압증기 양 생 방법을 사용한다 ${ }^{4-5)}$. 특히 프리캐스트 모르타르 및 콘크리트 제품은 수화반응을 촉진하여 물리적 특성을 좀 더 빠르게 발현한다. 이에 따라 품질관리가 용이하 며, 내구성 증대 및 공기단축이 가능하고 공사비 절감 등의 부대효과도 동반된다 ${ }^{6-8)}$. 수열합성법은 물 또는 수 용액을 승온, 승압하여 결정을 생성시키는 방법으로 분 산성이 좋으며 균일한 결정성을 갖는 고용체 화합물을 얻기 쉬운 특징이 있다. 그리고 결정질 분말을 하소 과 정 없이 얻을 수 있으며, 다른 방법들에 비해 비교적 분말의 조성과 제어가 용이하다. 일반적으로 수열합성 의 온도는 물이 끊는점과 임계 온도 사이에서 행해지며 압력은 자생압력(Autogenous pressure)에서부터 수십
$\mathrm{MPa}$ 의 범위까지 다양하게 가해지게 된다. 또한 수열합 성 시 사용되는 용액은 수열합성과정에서 압력과 열을 전달매체로 사용되어 반응제, 촉매, 용매, 표면흡착제 등 의 다양한 역할을 하며, 화학반응을 통한 결정화를 촉 진시키고 이온 교환이나 추출 시에 반응 용매의 역할과 침식 및 고화 작용제등의 다양한 역할을 담당한다.

따라서 본 연구에서도 중석 광미를 골재 대체재로 사 용하여 모르타르를 제조 하고자 하였으며, 제조된 모르 타르를 상압 및 고압증기 양생방법으로 양생하였다. 양 생이 종료된 모르타르의 물리특성 및 수화특성을 검토 하여 중석 광미의 골재 대체 가능성을 분석·평가하였다.

\section{2. 실험 방법}

중석 광미를 사용한 모르타르의 특성 평가를 위해 저 비소 광미 $(\mathrm{W})$ 및 고비소 광미(WAs)를 입수하여 물리. 화학적 특성 평가를 실시하였다. 중석 광미의 특성 평 가는 습식 화학분석기(OPTIMA5300DV, Perkin-Elmer 社, 미국)를 이용한 화학성분 분석 및 유해물질 용출량 평가(환경부 고시 폐기물공정시험방법), 입도분석기(LA$950 \mathrm{~V} 2$, Horiba社, 일본) 및 비표면적 분석기(ASAP2420, Micromeriticsi社, 미국)를 이용한 입도특성 분석, X-선 회절분석기(D5005D, Ziemensi社, 독일)를 이용한 결정 상 분석을 실시하였다.

중석 광미의 입도 특성에 따른 모르타르 특성 평가를 위해 진동밀(WTVM, 웅비기계社, 한국)을 이용하여 중 석 광미를 분쇄하였다. Fig. 1과 같이 배치식 진동밀을 이용하여 중석 광미를 분쇄하였으며, 분쇄 시간을 각각 15 분, 30 분 및 60 분으로 제어하여 분쇄 시간에 따른 중석 광미의 입도 특성을 평가하였다. 입도 특성 평가 방법으로는 비표면적 분석기 및 입도분석기를 이용하여 시료의 비표면적, 평균 입경 등을 분석·평가하였다.

입도 제어를 완료한 중석 광미를 사용하여 모르타르 제조 실험을 실시하였다. Fig. 2에서와 같이 모르타르의 주요 원료로 1종 보통 포틀랜드시멘트(OPC), 모래(합천

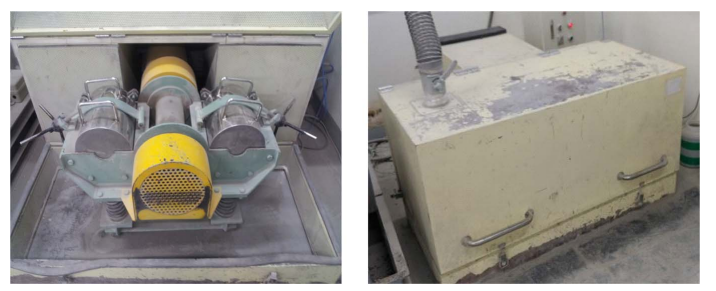

Fig. 1. Vibratory mill.

자원리싸이클링 제 28 권 제 6 호, 2019 


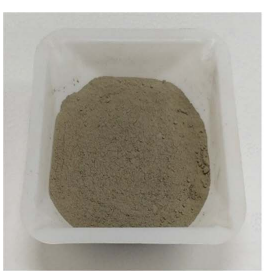

(a) OPC

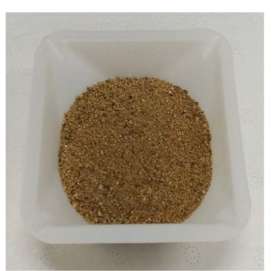

(b) Sand

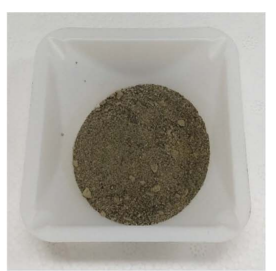

(c) Tailing(W)

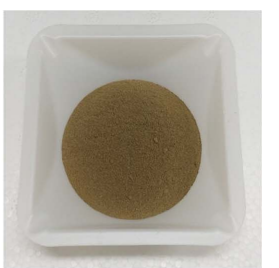

(d) Tailing(WAs)

Fig. 2. Main starting materials.

강모래 6호사) 및 2종의 중석 광미(저비소 및 고비소 광미)를 사용하였다. $\mathrm{OPC}$ 의 주성분은 $\mathrm{CaO}(62.12 \%)$, $\mathrm{SiO}_{2}(21.82 \%)$ 였으며, 비중은 $3.15 \mathrm{~g} / \mathrm{cm}^{3}$, 모래의 $\mathrm{SiO}_{2}$ 함량은 $91 \%$ 수준, 비중은 $2.65 \mathrm{~g} / \mathrm{cm}^{3}$ 이었다. 모르타르 제조를 위한 중석 광미의 최적 혼합비율 도출을 위해 배합설계비를 설정하였으며, 이를 Table 1에 나타내었다. 시멘트 모르타르 혼합 시 물-시멘트비(Water/Cement ratio)는 $75 \%$ 로, 모래-시멘트비(Sand/Cement ratio)를 $400 \%$ 로 고정하였으며, “시멘트의 강도 시험 방법(KS L ISO 679)"에 준하여 시멘트 모르타르를 혼합하였다. 중석 광미는 모래를 치환하여 사용하였으며, 치환률은 혼합 모래 중량 대비 $0 \sim 50 \%$ 로 제어하였다. 이때 중 석 광미를 치환하지 않은 시편을 비교시편으로 하였다.

혼합이 종료된 모르타르를 $5 \times 5 \times 5 \mathrm{~cm}$ 크기의 시편으 로 성형하였으며, $23{ }^{\circ} \mathrm{C} \sim 90 \%$ R.H.로 제어된 항온항 습기에서 24시간동안 양생하였다. 이후 Fig. 3의 오토 클레이브(J-AT3, Jisico社, 한국)를 이용하여 수열합성하 였다. Fig. 4에서와 같이 각 배합조건별 수열합성 온도 를 $60{ }^{\circ} \mathrm{C}, 120^{\circ} \mathrm{C}$ 및 $180{ }^{\circ} \mathrm{C}$ 로 제어하였고 각 목표온 도까지의 승온 속도는 분당 $2{ }^{\circ} \mathrm{C}$ 로 고정하였으며, 목표 온도 도달 후 6시간 동안 유지하여 수열합성 반응이 충 분히 이루어지도록 하였다. 수열합성이 종료된 시편은 “수경성 시멘트 모르타르의 압축 강도 시험 방법 $(\mathrm{KS} \mathrm{L}$

Table 1. Mixing ratio of mortar

\begin{tabular}{|c|c|c|c|c|c|}
\hline & $\mathrm{W} / \mathrm{C}$ & $\mathrm{S} / \mathrm{C}$ & OPC & Sand & W/WAs \\
\hline $0 \%(\mathrm{REF})$ & \multirow{6}{*}{75} & \multirow{6}{*}{400} & \multirow{6}{*}{100} & 400 & 0 \\
\hline $10 \%$ & & & & 360 & 40 \\
\hline $20 \%$ & & & & 320 & 80 \\
\hline $30 \%$ & & & & 280 & 120 \\
\hline $40 \%$ & & & & 240 & 160 \\
\hline $50 \%$ & & & & 200 & 200 \\
\hline
\end{tabular}
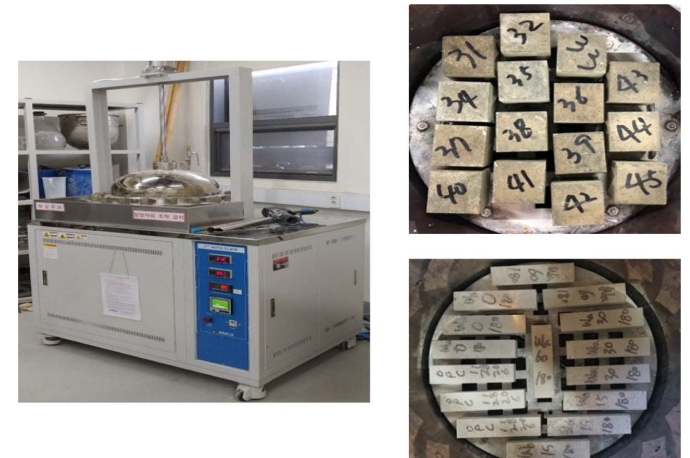

Fig. 3. Autoclave and thermal hydration sample.

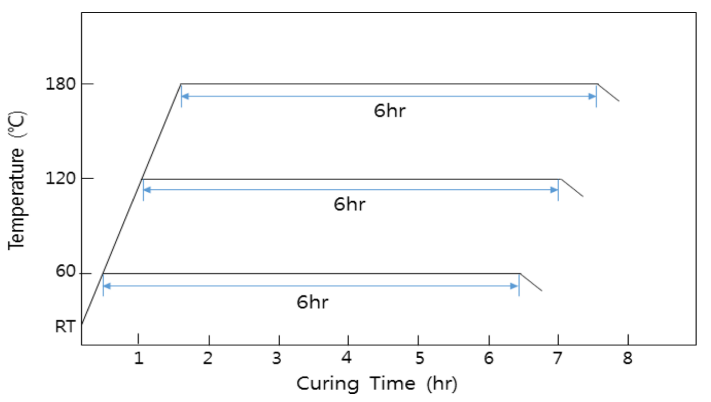

Fig. 4. Thermal hydration program.

$5105)$ "에 따라 압축강도를 측정하였다.

\section{3. 결과 및 고찰}

\section{1. 원료 특성 분석}

저비소 및 고비소 광미를 입수하여 물리·화학적 특성 평가를 실시하였다. Table 2에서와 같이 중석 광미의 비중은 $2.90 \mathrm{~g} / \mathrm{cm}^{3}$ 수준으로써, 모래의 비중 $\left(2.65 \mathrm{~g} / \mathrm{cm}^{3}\right)$ 보다 약간 높은 값이었다. 저비소 광미의 주성분은 $\mathrm{SiO}_{2}-58.50 \%, \mathrm{Fe}_{2} \mathrm{O}_{3}-12.00 \%$ 이었으며, 고비소 광미는 $\mathrm{SiO}_{2}-47.70 \%, \mathrm{Fe}_{2} \mathrm{O}_{3}-12.00 \%$ 등으로 나타났다. 아울러 인체·환경에 유해한 $\mathrm{Cr}_{2} \mathrm{O}_{3}$ 및 $\mathrm{As}_{2} \mathrm{O}_{3}$ 가 소량 검출되으 
Table 2. Chemical composition and density of tungsten tailing

\begin{tabular}{|c|c|c|c|c|c|c|c|c|c|c|}
\hline $\begin{array}{c}\text { Chem. Comp. } \\
\text { Sample Name }\end{array}$ & $\mathrm{SiO}_{2}$ & $\mathrm{Al}_{2} \mathrm{O}_{3}$ & $\mathrm{Fe}_{2} \mathrm{O}_{3}$ & $\mathrm{CaO}$ & $\mathrm{MgO}$ & $\mathrm{K}_{2} \mathrm{O}$ & LOI & $\mathrm{Cr}_{2} \mathrm{O}_{3}$ & $\mathrm{As}_{2} \mathrm{O}_{3}$ & $\begin{array}{c}\text { Density } \\
\left(\mathrm{g} / \mathrm{cm}^{3}\right)\end{array}$ \\
\hline W & 58.5 & 8.85 & 12.0 & 9.76 & 2.37 & 1.63 & 3.28 & $<0.01$ & 0.01 & 2.90 \\
\hline WAs & 47.7 & 7.60 & 12.0 & 9.89 & 19.1 & 1.43 & 4.00 & 0.01 & 0.07 & 2.91 \\
\hline
\end{tabular}

Table 3. Heavy metal dissolution of tungsten tailing

\begin{tabular}{|c|c|c|c|c|c|c|}
\hline Element & $\mathrm{Pb}$ & $\mathrm{Cd}$ & $\mathrm{As}$ & $\mathrm{Hg}$ & $\mathrm{Cu}$ & $\mathrm{Cr}^{6+}$ \\
\hline $\mathrm{W}$ & N.D. ${ }^{6}$ & N.D. & N.D. & N.D. & N.D. & N.D. \\
\hline WAs & N.D. & N.D. & N.D. & N.D. & N.D. & N.D. \\
\hline
\end{tabular}

*N.D.: Not Detected

며, 따라서 중석 광미를 사용하여 콘크리트 제품 등을 제조할 경우 환경·인체 유해성 등을 평가해야 할 것으 로 사료되었다 ${ }^{9)}$.

중석 광미의 유해물질 용출량을 평가하기 위해 “폐기 물공정시험방법(환경부 고시)"에 따라 중금속 용출시험 을 실시하였으며, 그 결과를 Table 3에 나타내었다. 중 금속 용출시험 결과 비소(As), 6 가 크롬 $\left(\mathrm{Cr}^{6+}\right)$ 및 구리 $(\mathrm{Cu})$ 등의 중금속이 용출되지 않는 것으로 나타났다.

저비소 광미의 결정상을 분석하기 위해 $\mathrm{X}$-선 회절분 석기를 이용하였으며, 그 결과를 Fig. 5에 나타내었다. $\mathrm{X}$-선 회절 분석 결과 중석 광미의 주결정상은 Quartz $\left(\mathrm{SiO}_{2}\right)$ 로 나타났으며, 일부 석회석 $\left(\mathrm{CaCO}_{3}\right)$ 피크도 검출 되었다. 일반적으로 시멘트 모르타르 제조 시 잔골재로 사용되고 있는 모래의 주요 화학성분은 $\mathrm{SiO}_{2}(90 \%$ 수 준)로써 주결정상은 Quartz로 이루어져 있다. 본 실험에 사용한 중석 광미의 경우 Quartz의 결정성이 상당히 강 하게 나타난 것을 확인할 수 있으며, 이는 모르타르 제 조 시 모래 대체재로써 중석 광미를 사용할 수 있을 것으로 사료되었다.

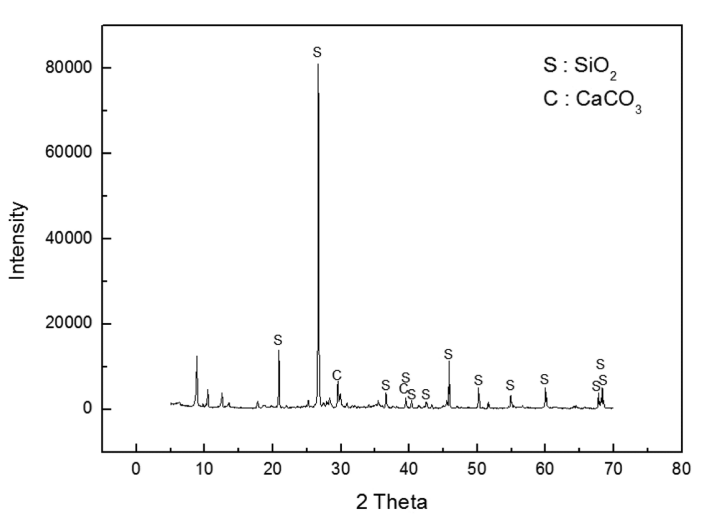

Fig. 5. XRD Pattern of low Arsenic tailing.

\section{2. 분쇄 특성}

중석 광미의 입도 특성에 따른 모르타르 제조 및 특 성 평가를 위해, 진동밀을 이용하여 중석 광미를 분쇄 하였다. 분쇄 시간에 따른 중석 광미의 특성을 분석하 기 위해 진동밀의 분쇄 시간을 0 분, 15 분, 30 분 및 60 분으로 제어한 후, 입도 분석기를 이용하여 평균 입경

Table 4. Particle size as milling time of tungsten tailing

\begin{tabular}{|c|c|c|c|c|c|c|c|c|}
\hline \multirow{2}{*}{ Milling Time } & \multicolumn{3}{|c|}{ W Unit : $\mu \mathrm{m})$} \\
\cline { 2 - 10 } & $0 \mathrm{~min}$ & $15 \mathrm{~min}$ & $30 \mathrm{~min}$ & $60 \mathrm{~min}$ & $0 \mathrm{~min}$ & $15 \mathrm{~min}$ & $30 \mathrm{~min}$ & $60 \mathrm{~min}$ \\
\hline Median size $(\mu \mathrm{m})$ & 39.04 & 21.10 & 12.47 & 9.36 & 36.63 & 14.36 & 10.86 & 8.43 \\
\hline Mean size $(\mu \mathrm{m})$ & 52.04 & 30.15 & 13.96 & 10.35 & 51.06 & 16.73 & 12.19 & 9.26 \\
\hline
\end{tabular}


Table 5. Surface area as milling time of tungsten tailing

\begin{tabular}{|c|c|c|c|c|}
\hline Milling Time & $0 \mathrm{~min}$ & $15 \mathrm{~min}$ & $30 \mathrm{~min}$ & $60 \mathrm{~min}$ \\
\hline $\begin{array}{c}\text { Surface area } \\
\left(\mathrm{m}^{2} / \mathrm{g}\right)\end{array}$ & 1.28 & 1.58 & 2.58 & 3.45 \\
\hline
\end{tabular}

을 측정하였으며 결과를 Table 4에 나타내었다.

입도 분석기를 이용한 입도분포 측정 결과, 분쇄하지 않은 저비소 및 고비소 광미의 평균 입경은 각각 $52.04 \mu \mathrm{m}$ 및 $51.06 \mu \mathrm{m}$ 수준이었다. 분쇄 시간이 15 분, 30 분 및 60 분으로 증가함에 따라 저비소 광미 및 고비 소 광미의 평균 입경은 각각 $30.15 \mu \mathrm{m} \rightarrow 13.96 \mu \mathrm{m}$ $\rightarrow 10.35 \mu \mathrm{m}$ 및 $16.73 \mu \mathrm{m} \rightarrow 12.19 \mu \mathrm{m} \rightarrow 9.26 \mu \mathrm{m}$ 으로, 감소폭이 낮아지고 있는 것을 확인할 수 있었다. 비표면적 측정기(BET)를 이용하여 진동밀 분쇄 시간 에 따른 저비소 광미 $(\mathrm{W})$ 의 비표면적을 측정하였으며, 그 결과를 Table 5에 나타내었다. 분쇄하지 않은 저비 소 광미의 비표면적은 $1.28 \mathrm{~m}^{2} / \mathrm{g}$ 으로 나타났으며, 분쇄 시간이 증가함에 따라 $1.58 \rightarrow 2.58 \rightarrow 3.45 \mathrm{~m}^{2} / \mathrm{g}$ 으
로 측정되었다. 즉, 입도분포 측정결과와 마찬가지로 분 쇄 시간이 증가함에 따라 중석 광미의 입경은 작아지고 있으며, 비표면적이 증가하고 있는 것을 확인할 수 있 었다.

\section{3. 모르타르 압축강도}

시멘트 모르타르 제조를 위한 물-시멘트비(Water/ Cement ratio)는 $75 \%$ 로, 모래-시멘트비(Sand/Cement ratio)를 $400 \%$ 로 고정하였다. 중석 광미는 혼합 모래 중량 대비 $0 \sim 50 \%$ 로 치환하였고 혼합을 마친 모르타 르는 $5 \times 5 \times 5 \mathrm{~cm}$ 크기의 시편으로 제조하였으며, 항온항 습기에서 양생 과정을 거친 후 오토클레이브를 이용하 여 수열합성을 실시하였다. 수열합성이 종료된 시편은 만능재료시험기(UTM, Universal Testing Machine)를 이용하여 압축강도를 측정하였다.

$60{ }^{\circ} \mathrm{C} \sim 6$ 시간 조건으로 수열합성한 시편의 분쇄시간 별-혼합조건별 압축강도를 Table 6에 나타내었다. 중석 광미 혼합량 증가에 따라 압축강도가 증가하는 경향을 나타내었다. 그러나 중석 광미를 $50 \%$ 이상 혼합할 경

Table 6. Compressive strength of $60^{\circ} \mathrm{C} \sim 6 \mathrm{hr}$ mortar

(Unit : MPa)

\begin{tabular}{|c|c|c|c|c|c|c|c|c|}
\hline \multirow{2}{*}{ Mixing Ratio (\%) } & \multicolumn{4}{|c|}{ W } & \multicolumn{4}{|c|}{ WAs } \\
\hline & $0 \min$ & $15 \mathrm{~min}$ & $30 \mathrm{~min}$ & $60 \mathrm{~min}$ & $0 \mathrm{~min}$ & $15 \mathrm{~min}$ & $30 \mathrm{~min}$ & $60 \mathrm{~min}$ \\
\hline 0 (REF) & \multicolumn{8}{|c|}{8.9} \\
\hline 10 & 9.0 & 9.3 & 12.2 & 17.2 & 8.0 & 12.9 & 13.5 & 15.6 \\
\hline 20 & 7.2 & 15.7 & 17.4 & 22.4 & 12.4 & 17.2 & 22.3 & 19.9 \\
\hline 30 & 10.1 & 19.4 & 23.6 & 23.6 & 17.3 & 21.5 & 23.0 & 22.2 \\
\hline 40 & 10.7 & 21.2 & 21.7 & 19.5 & 9.7 & 14.2 & 17.4 & 17.5 \\
\hline 50 & 6.9 & 16.3 & 14.9 & 13.5 & 12.4 & 12.4 & 10.8 & 13.6 \\
\hline
\end{tabular}

Table 7. Compressive strength of $120^{\circ} \mathrm{C} \sim 6 \mathrm{hr}$ mortar

\begin{tabular}{|c|c|c|c|c|c|c|c|c|}
\hline \multicolumn{9}{|c|}{ W Unit : MPa) } \\
\hline \multirow{2}{*}{ Mixing Ratio (\%) } & \multicolumn{7}{|c|}{ WAs } \\
\cline { 2 - 9 } & $0 \mathrm{~min}$ & $15 \mathrm{~min}$ & $30 \mathrm{~min}$ & $60 \mathrm{~min}$ & $0 \mathrm{~min}$ & $15 \mathrm{~min}$ & $30 \mathrm{~min}$ & $60 \mathrm{~min}$ \\
\hline 0 (REF) & \multicolumn{7}{|c|}{16.5} \\
\hline 10 & 13.0 & 20.0 & 20.3 & 24.2 & 15.0 & 20.0 & 22.7 & 23.4 \\
\hline 20 & 16.9 & 19.2 & 21.3 & 22.4 & 17.7 & 19.9 & 33.8 & 34.9 \\
\hline 30 & 18.5 & 22.8 & 35.0 & 41.0 & 22.5 & 29.8 & 36.3 & 40.8 \\
\hline 40 & 17.8 & 28.3 & 37.1 & 34.7 & 21.1 & 28.9 & 30.9 & 34.8 \\
\hline 50 & 11.2 & 26.1 & 27.4 & 28.6 & 20.4 & 24.1 & 22.6 & 29.7 \\
\hline
\end{tabular}


Table 8. Compressive strength of $180{ }^{\circ} \mathrm{C} \sim 6 \mathrm{hr}$ mortar

\begin{tabular}{|c|c|c|c|c|c|c|c|c|}
\hline \multirow{2}{*}{ Mixing Ratio (\%) } & \multicolumn{4}{|c|}{ W } & \multicolumn{4}{|c|}{ WAs } \\
\hline & $0 \mathrm{~min}$ & $15 \mathrm{~min}$ & $30 \mathrm{~min}$ & $60 \mathrm{~min}$ & $0 \mathrm{~min}$ & $15 \mathrm{~min}$ & $30 \mathrm{~min}$ & $60 \mathrm{~min}$ \\
\hline 0 (REF) & \multicolumn{8}{|c|}{16.7} \\
\hline 10 & 15.7 & 20.6 & 25.2 & 34.4 & 20.0 & 30.1 & 30.9 & 35.2 \\
\hline 20 & 15.6 & 31.4 & 24.0 & 45.3 & 25.3 & 44.4 & 39.7 & 50.0 \\
\hline 30 & 17.8 & 37.7 & 45.2 & 55.2 & 23.0 & 47.0 & 40.9 & 54.5 \\
\hline 40 & 25.8 & 36.5 & 41.6 & 52.2 & 30.2 & 43.8 & 44.1 & 45.3 \\
\hline 50 & 19.3 & 36.4 & 43.9 & 55.1 & 29.8 & 36.4 & 35.2 & 36.0 \\
\hline
\end{tabular}

우 시편의 압축강도가 낮아지는 것을 확인할 수 있었다. 분쇄 시간이 증가함 $(0$ 분 $\rightarrow 15$ 분 $\rightarrow 30$ 분 $)$ 에 따라 중석 광미 혼합 시편의 압축강도가 증가하는 경향을 나타내 었다 ${ }^{10)}$. 그러나 중석 광미의 분쇄시간이 60 분으로 증가 할 경우, 압축강도는 더 이상 증가하지 않거나 감소하 는 경항을 나타내었다. 중석 광미를 혼합하지 않은 시 편(비교시편)의 압축강도는 $8.9 \mathrm{MPa}$ 로 나타났으며, 저 비소 및 고비소 광미를 30 분 분쇄한 시료를 $30 \%$ 혼 합할 경우 가장 높은 압축강도값 $(23.6 \mathrm{MPa}, 23.0 \mathrm{MPa})$ 을 나타내었다. 이는 비교시편의 압축강도보다 약 $265 \%$ 수준 향상된 값으로써, 30 분 분쇄한 중석 광미 를 $30 \%$ 혼합하여 기능성 블록을 제조할 경우 상당히 양호한 물리 특성을 발현할 것으로 사료되었다. 저비소 및 고비소 광미의 혼합량이 증가할수록 압축강도 또한 증가하는 것으로 분석되었다. 그러나 중석 광미의 혼합 량이 $40 \%$ 를 초과할 경우 압축강도는 오히려 감소하였 다. 따라서 중석 광미의 적정 혼합량은 약 $30 \%$ 수준 인 것으로 판단되었다. 분쇄하지 않은 저비소 광미의 경 우, 모든 배합조건에서 비교시편과 유사한 압축강도 값 이 발현되었다.

$120{ }^{\circ} \mathrm{C} \sim 6$ 시간 조건으로 수열합성한 시편의 분쇄시 간별-혼합조건별 압축강도를 Table 7에 나타내었다. 중 석 광미를 혼합하지 않은 시편(비교시편)의 압축강도는 $16.5 \mathrm{MPa}$ 로 나타났으며, 저비소 광미 $(\mathrm{W})$ 를 60 분 분쇄 하여 $30 \%$ 혼합할 경우 가장 높은 압축강도값(41.0 $\mathrm{MPa}$ )을 나타내었다. 중석 광미 혼합량에 따른 압축강도 특성은 $60{ }^{\circ} \mathrm{C}-6$ 시간 조건과 유사한 경향을 나타내었다. 즉, 중석 광미를 $30 \sim 40 \%$ 혼합할 경우 압축강도는 증 가하였으며, $50 \%$ 이상 혼합할 경우 압축강도가 감소하 였다. 아울러 대부분의 혼합조건에서 중석 광미의 분쇄 시간이 증가함에 따라 시편의 압축강도 또한 향상하는
것으로 나타났다.

$180^{\circ} \mathrm{C} \sim 6$ 시간 조건으로 수열합성한 시편의 분쇄시 간별-혼합조건별 압축강도를 Table 8에 나타내었다. 중 석 광미 혼합량이 증가함에 따라 압축강도가 증가하는 경향을 나타내었다. 그러나 $60{ }^{\circ} \mathrm{C}$ 및 $120^{\circ} \mathrm{C}$ 조건과 마 찬가지로, 중석 광미를 $50 \%$ 이상 혼합할 경우 시편의 압축강도가 감소하는 것을 확인할 수 있었다. 또한 분 쇄 시간이 증가함에 따라 압축강도도 향상하는 것으로 나타났다. 중석 광미를 혼합하지 않은 시편(비교시편)의 압축강도는 $16.7 \mathrm{MPa}$ 로 나타났으며, 저비소 광미 및 고 비소 광미를 60 분 분쇄하여 $30 \%$ 혼합한 시편의 압축 강도는 각각 $55.2 \mathrm{MPa}$ 및 $54.5 \mathrm{MPa}$ 로 나타났다. 이는 비교시편 압축강도와 비교하여 약 $300 \%$ 이상 향상된 수준으로써 상당히 양호한 결과를 도출할 수 있었다.

상기의 압축강도 실험결과를 살펴보면, 대부분의 실 험결과에서 중석 광미를 60 분 분쇄하여 $30 \%$ 혼합할 경우 압축강도가 가장 높게 나타난 것을 확인할 수 있 었다. 일반적으로 수열합성은 시편의 물리적 특성을 빠 르게 발현하여 품질관리가 용이하며, 내구성 증대 및 공 기단축이 가능하고, 공사비 절감 등의 특징이 있다. 아 울러 시편의 강도를 결정하는 수열합성 수화물의 종류 는 배합물의 $\mathrm{CaO} / \mathrm{SiO}_{2}$ 몰비 및 수열합성 온도에 따라 결정된다. 또한 모르타르의 강도는 시편의 기공률과도 관계가 있으며, 따라서 분쇄 시간 증가에 따라 시편의 기공이 충진 되었으며, 혼합량 변화에 따라 $\mathrm{CaO} / \mathrm{SiO}_{2}$ 몰비가 최적화되어 압축강도가 높게 발현된 결과라 사 료된다.

\section{4. 결 론}

본 연구에서는 매립 처리되어 있는 중석 광미의 유용 
자원화 및 환경보호를 위한 방안으로, 수열합성법을 이 용한 모르타르 제조 기술을 검토하였다. 중석 광미를 활 용하기 위해 다수의 실험인자(중석 광미의 입도특성 및 혼합비율 제어, 수열합성 조건 제어 등)를 검토하였으 며, 다음과 같은 결론을 도출하였다.

1. 저비소 광미의 주성분은 $\mathrm{SiO}_{2} 58.50 \%, \mathrm{Fe}_{2} \mathrm{O}_{3}$ $12.00 \%$ 이었으며, 고비소 광미는 $\mathrm{SiO}_{2} 47.70 \%, \mathrm{Fe}_{2} \mathrm{O}_{3}$ $12.00 \%$ 등으로 나타났다. 비중은 $2.90 \mathrm{~g} / \mathrm{cm}^{3}$ 으로써 블 록의 잔골재로 사용되는 모래보다 약간 높은 수준이었다.

2. 중석 광미는 소량의 $\mathrm{Cr}_{2} \mathrm{O}_{3}$ 및 $\mathrm{As}_{2} \mathrm{O}_{3}$ 가 검출되었 으며, 폐기물공정시험방법에 따른 중금속 용출시험 결 과 비소(As), 6 가 크롬 $\left(\mathrm{Cr}^{6+}\right)$ 등의 중금속이 용출되지 않는 것으로 나타났다.

3. 중석 광미의 입도에 따른 기능성 블록의 특성 평 가를 위해 진동밀을 이용하여 중석 광미를 분쇄하였다. 분쇄 시간이 0 분, 15 분, 30 분 및 60 분으로 증가함에 따라 저비소 및 고비소 광미의 평균 입경은 각각 $52.04 \mu \mathrm{m} \rightarrow 30.15 \mu \mathrm{m} \rightarrow 13.96 \mu \mathrm{m} \rightarrow 10.35 \mu \mathrm{m}$ 및 $51.06 \mu \mathrm{m} \rightarrow 16.73 \mu \mathrm{m} \rightarrow 12.19 \mu \mathrm{m} \rightarrow 9.26 \mu \mathrm{m}$ 로 나타났다.

4. 수열합성 온도별 압축강도는 일부 배합을 제외한 모든 시편에서 수열합성 온도가 증가함에 따라 압축강 도 특성이 우수하게 나타나는 것을 확인할 수 있었다. 또한 모든 수열합성 조건에서 중석 광미의 혼합량이 증 가할 경우 압축강도 또한 향상되는 것으로 나타났다.

5. 중석 광미를 60 분 분쇄하여 $30 \%$ 혼합한 시편의 압축강도는 비교시편 압축강도와 비교하여 약 $300 \%$ 이상 향상되는 결과를 도출할 수 있었다. 그러나 중석 광미를 $50 \%$ 이상 혼합할 경우에는 압축강도가 소폭 낮아지는 것으로 확인되었다.

\section{References}

1. Y. J. Kim, Y. J. Kim, Y. E. Choi et al., 2013 : Availability Review of Tailings from the Sangdong Tungsten Mine as a Material for Construction, Journal of Korean Recycled Construction Resources Institute, 1(3), pp.204-210.

2. Y. W. Choi, M. Y. Jung, M. C. Jung et al., 2005 : Properties of Compressive Strength of Mortar Mixed with Tailings from the Sangdong Tungsten Mine for Soil Pavement, The
Korean Institute of Resources Recycling, pp.224-227.

3. Y. W. Choi, Y. J. Kim, and W. Choi, 2006 : The Quality Properties of Self-Compacting Concrete Mixed with Tailing from the Sangdong Tungsten Mine, Journal of the Korea Concrete Institute, 18(6), pp.777-783.

4. S. K. Seo, Y. S. Chu, J. K. Lee et al., 2013 : A Study on Fabrication and Characterization of Inorganic Insulation Material by Hydrothermal Synthesis Method(2), Journal of Korean Recycled Construction Resources Institute, 1(3), pp.225-232.

5. J. H. Kim, J. K. Lee, and W. G. Hyung, 2013 : Properties of Alkali-Activated Cement Mortar by Curing Method, Journal of the Korea Concrete Institute, 26(2), pp.117-124.

6. G. Y. Park, G. Y. Kim, and G. C. Choe, 2014 : Evaluation of Early Compressive Strength of Concrete Using Early Strength Improvement Type Cement and Early Strength Activator, The Korea Institute of Building Construction, 14(4), pp.322-328.

7. Y. H. Kim, T. H. Song, and S. H. Lee, 2011 : Hydrothermal Reactivity Analysis for Hardened Cement Matrix Using Crushed Stone Powder, Korea Society of Waste Management, 28(6), pp.584-593.

8. H. S. Kwon, S. J. Kim, M. H. Gong et al., 2008 : An Experimental Study on the Strength Development of High Strength Mortar by Steam Curing, Architectural Institute of Korea, 24(7), pp.85-92.

9. E. H. Kim, J. K. Kim, and N. C. Seok, 1997 : A Study on Recycle of Waste Concretes for Neutralization and Removal of Heavy Metals, The Korean Environmental Sciences Society, 6(5), pp.497-503.

10. M. C. Han, 2009 : Estimation of Compressive Strength of Concrete Incorporation Fine Particle Cement Considering Blaine Fineness, The Korea Institute of Building Construction, 9(4), pp.139-145.

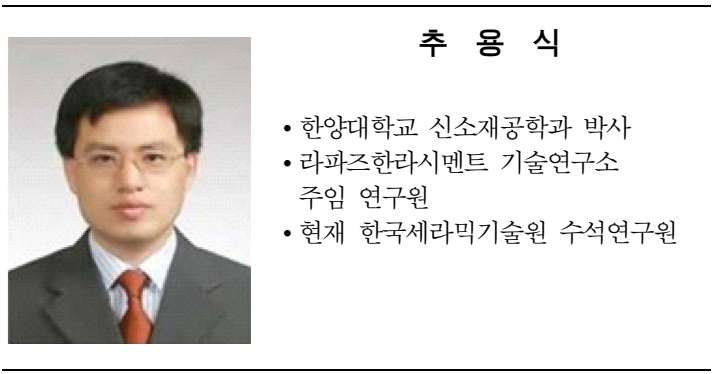




\section{서 성 관}

• 한양대학교 신소재공학과 공학박사

• 현재 한국세라믹기술원 에너지환경본부

선임연구원

\section{최 성 범}

- 강원대학교 자원공학과 공학박사

• 현재 영월산업진흥원 광물소재사업팀 팀장

\section{김 경 만}

- 강원대학교 자원공학과 공학박사

- 현재 영월산업진흥원 광물소재사업팀

선임연구원
홍 석 환

- 강원대학교 화학공학과 공학석사

- 현재 영월산업진흥원 광물소재사업팀 전임연구원

《광 고》 本 學會에서 發刊한 자료를 판매하오니 學會사무실로 문의 바랍니다.

*EARTH '93 Proceeding(1993) 457쪽, 價格 : 20,000원

(The 2th International Symposium on East Asian Resources Recycling Technology)

* 자원리싸이클링의 실제(1994) 400쪽, 價格 : 15,000 원

* 학회지 합본집 I X 價格 : 40,000원, 50,000원(비회원)

(I : 통권 제 1 호 제 10 호, II : 통권 제 11 호 제 20 호, III : 통권 제 21 호 제 30 호, IV : 통권 제 31 제 40 호, $\mathrm{V}$ : 통권 제 41 호 제 50 호, VI: 통권 제 51 호 제 62 호, VII: 통권 제 63 호 제 74 호, VIII: 통권 제 75 호 제 86 호 IX: 통권 제 87 호 제 98 호, X: 통권 제99호 제 110 호)

* 한·일자원리싸이클링공동워크샵 논문집(1996) 483쪽, 價格 : 30,000원

* 한·미자원리싸이클링공동워크샵 논문집(1996) 174쪽, 價格 : 15,000 원

* 자원리싸이클링 총서I(1997년 1월) 311쪽, 價格 : 18,000원

*'97 미주 자원재활용기술실태조사(1997년) 107쪽, 價格 : 15,000원

* 日本의 리싸이클링 產業(1998년 1월) 395쪽, 價格 : 22,000원, 발행처-文知社

*EARTH 2001 Proceeding (2001) 788쪽, 價格 : 100,000원 (The 6th International Symposium on East Asian Resources Recycling Technology)

* 오재현의 자동차 리싸이클링기행(2003년 2월) 312쪽, 價格 : 20,000원, 발행처-MJ미디어

* 리싸이클링백서(자원재활용백서, 1999년) 440쪽, 價格 : 15,000원, 발행처-文知社

* 리싸이클링백서(자원재활용백서, 2004년) 578쪽, 價格 : 27,000 원, 발행처-淸文閣

* 리싸이클링백서(자원재활용백서, 2009년) 592쪽, 價格 : 30,000원, 발행처-淸文閣

*EARTH 2009 Proceeding (2009) 911쪽, 價格 : 100,000원

(The 10th International Symposium on East Asian Resources Recycling Technology)

* 리싸이클링백서(자원재활용백서, 2014년) 435쪽, 價格 : 35,000원, 발행처-S\&M미디어(주) 